\title{
SHORT-TERM TRENDS IN BASTARDY IN TAIWAN
}

\author{
Richard E. Barrett*
}

By international standards, bastardy was a relatively common occurrence in Taiwan during the Japanese colonial period (18951945). This may come as somewhat of a surprise to many of those familiar with anthropological accounts of Chinese populations; in most of these studies, illegitimacy is presented as a rare phenomenon. ${ }^{1}$

*Richard E. Barrett was awarded the Ph.D. in sociology in 1978 by the University of Michigan. He is now Assistant Professor in the Department of Sociology at the University of Illinois, Chicago Circle.

The author would like to thank Martin Whyte, Ronald Freedman, John Knodel, Arthur Wolf, William Lavely, and John Casterline for their suggestions and criticisms; of course, final responsibility for the ideas and interpretations presented here rests with the author. In addition, the staffs of the Institute of Ethnology, Academia Sinica, and the Taiwan Branch Library of the National Central Library (both are in Taipei, Taiwan), and of the Orientalia Division, United States Library of Congress, deserve thanks; their policies of allowing researchers free access to their stacks had a direct effect on the discovery of some of the findings reported in this paper.

'See, for example, Levy, 1968:337; or Yang, 1968: 118-121. Illegitimacy on mainland China was generally ascribed to the penetration of urban or "modern" influences into the traditional family system.

There appear to be three major reasons for this portrayal of Chinese bastardy. First, many of the English-language anthropological studies of China in the 1920-1949 period appear to be conscious attempts to emphasize the more "normal" or mundane aspects of village or family life as an antidote to missionaries' horror stories or Western imperialist apologists' picture of China as a "decadent" culture which deserved the foreign exploitation to which it was subjected.
In recent years, historical demographers have published a considerable amount on European patterns of illegitimacy during the last century (Shorter, Knodel, and van de Walle, 1971), and on certain smaller areas for longer periods of time (e.g., Laslett, 1977:102-159). Yet for China, aside from Arthur Wolf's pioneering work with Taiwanese household registers from the Haishan district, we have almost no reliable data on illegitimacy (see Wolf, 1975; Wolf and Huang, 1980:251-260).

There are a number of levels at which the phenomenon of bastardy can be analyzed. One can study its prevalence, its social and economic context, its meaning for the parents or for the bastards themselves, or its prevalence as perceived by the local people and the meanings which they attach to it. Anthropologists of China have tended to concentrate on the latter two as-

Second, many of these studies were written at a time when "functionalism" was a dominant paradigm in British and American social science. While functionalism provided many insights into Chinese institutions, this view of social relations can lead to an overemphasis on the degree to which prevalent norms influence actual behavior.

Third, the field study of anthropologists may be a poor method by which to study bastardy. During the course of a year's stay in a village the anthropologist may witness few illegitimate births, or the nature of these births may be successfully concealed. The investigator who is dependent on the goodwill of his or her hosts may consciously or unconsciously avoid asking potentially embarrassing questions about the legitimacy of births in the area. 
pects; while information on such perceptions and norms is valuable, there is no necessary relation between such perceptions and the actual prevalence of bastardy. Hopefully, future anthropologists of China will distinguish more clearly which parts of their work are based on thorough investigation and which are largely the result of informed speculation or conjecture.

Of course, if one is to hold the anthropologist to such rarified standards of professional honesty, one should be willing to take a tentative step in this direction oneself. Thus it should be stressed that the data which will be presented below can only answer certain questions about the prevalence and distribution of illegitimacy, not about its social meaning for the Taiwanese. ${ }^{2}$

An analysis of the colonial vital statistics and census records shows that:

1. While the vast majority of Taiwanese women married at least once, there were frequent extramarital births to single, divorced, or widowed women.

2. The illegitimacy ratio and nonmarital fertility rates appear to have been on the increase from 1905 to 1935 , but decline slightly after that period.

3. Non-marital fertility rates in Taiwanese cities were little different from those prevalent in the surrounding countryside, and regional differences tended to be more striking than urban-rural ones.

4. Illegitimacy ratios of Hokkiens and Hakkas, the two major Chinese cultural groups, exhibit no systematic differences.

${ }^{2}$ The prevalence of illegitimacy, however, may well be related to its social meaning. The Chinese did have certain traditional mechanisms for the integration of bastard children into the ritual life of the community and for providing them with some access to resources. In Taiwan, for example, illegitimate children can participate in their father's funeral ritual (see Wolf in Freedman, 1970:194-195). Moreover, the Ch'ing dynasty inheritance code used in Taiwan provided for the rights of bastard sons as well as legitimate ones (see Okamatsu, 1971: appendix, xxiii).
5. Marital and non-marital age specific fertility rates indicate that the mothers of illegitimate children tend to be somewhat older than the mothers of legitimate children.

Most of the salient facts about the patterns of Taiwanese marriage, divorce, widowhood, and marital fertility have already been discussed by George Barclay (1954a:210-254). Most women married in their late teens, and husbands were usually about four or five years older than their wives. While the mean age at first marriage increased slightly for women, it declined for men during the period: in 1906 , the average age at first marriage was 18.1 years for women and 24.0 years for men, and in 1942, it was 19.0 years for women and 22.3 years for men (Bureau of Accounting and Statistics, 1946:190).

As Barclay has shown, between 1905 and 1935, 99 percent or more of all Taiwanese women over thirty-five years of age had married at least once. Yet relatively large numbers of them were widowed at early ages, and a sizeable number of them divorced or were divorced by their husbands. However, because of the strong propensity towards the remarriage of divorcees, and the tendency of younger widows to remarry, widows, divorcees, and single women constituted only a small proportion of women of childbearing age at any time (see Barclay, 1954a:216-237). ${ }^{3}$

Throughout the 1906-1943 period, the Japanese colonial police administered an efficient and highly accurate system of household registration (see Barclay, 1954b:

${ }^{3}$ Anthropologists and sociologists of China have belatedly taken heed of Barclay's convincing demonstration of the high rates of remarriage of widows and divorcees in Taiwan (see, for example, Freedman, 1966:59-67). From Barclay's work and my own investigation of the conditions of the marriage market in colonial Taiwan (see Barrett, 1978b), arguments that divorced or widowed women resorted to bastardy as a means of old-age security because they were unable to find husbands are not supported by fact. 
3-13; Chen, 1975:391-416; and Barrett, 1978a:68-88). With a few exceptions, field investigations by anthropologists and various statistical checks on reliability applied by demographers have shown that the data give an accurate picture of the actual demographic conditions of the time, and that the data are far more reliable than any extant data from the Chinese mainland (c.f. Cohen, 1976:19).

Apart from the efficiency and ubiquity of the colonial police-- the island may have had the world's highest ratio of police to people-the accuracy of the system was probably due in large part to the crosschecking of the quinquennial census results against the registration of vital events in the household registers, a procedure which reduced errors in both sets of data. Happily, this time-consuming procedure also permits later researchers to interfile census and vital statistics data in computing various demographic rates and measures.

TABLE 1. NUMBER OF LEGTIMATE AND ILLEGITIMATE BIRTHS AND BIRTHS TO CONCUBINES, AND SEX RATIOS AT BIRTH, TAWANESE WOMEN, SELECTED YEARS, 1906-1940.

\begin{tabular}{|c|c|c|c|c|}
\hline Year & Legitimate & Illegitimate & Concubine & Total \\
\hline \multicolumn{5}{|l|}{1906} \\
\hline Males & 60,165 & 1,389 & 566 & 62,120 \\
\hline Females & 55,150 & 1,298 & 539 & 56,987 \\
\hline Sex Ratio & 109 & 107 & 105 & 109 \\
\hline \multicolumn{5}{|l|}{1910} \\
\hline Males & 65,613 & 1,754 & 675 & 68,042 \\
\hline Females & 61,670 & 1,747 & 682 & 64,099 \\
\hline Sex Ratio & 106 & 100 & 99 & 106 \\
\hline \multicolumn{5}{|l|}{1915} \\
\hline Males & 68,099 & 2,064 & 692 & 70,855 \\
\hline Females & 64,138 & 2,048 & 628 & 66,814 \\
\hline Sex Ratio & 106 & 101 & 110 & 106 \\
\hline \multicolumn{5}{|l|}{1920} \\
\hline Males & 69,157 & 2,813 & 734 & 72,704 \\
\hline Females & 65,097 & 2,824 & 688 & 68,609 \\
\hline Sex Ratio & 106 & 100 & 107 & 106 \\
\hline \multicolumn{5}{|l|}{1925} \\
\hline Males & 77,541 & 3,311 & 807 & 81,659 \\
\hline Females & 73,609 & 3,405 & 750 & 77,764 \\
\hline Sex Ratio & 105 & 97 & 108 & 105 \\
\hline \multicolumn{5}{|l|}{1930} \\
\hline Males & 96,427 & 4,080 & 1,125 & 101,632 \\
\hline Females & 91,423 & 4,133 & 998 & 96,554 \\
\hline Sex Ratio & 105 & 99 & 112 & 105 \\
\hline \multicolumn{5}{|l|}{1935} \\
\hline Males & 109,712 & 5,083 & 1,327 & 116,122 \\
\hline Females & 103,691 & 4,938 & 1,229 & 109,858 \\
\hline Sex Ratio & 106 & 103 & 108 & 106 \\
\hline \multicolumn{5}{|l|}{1940} \\
\hline Males & 119,605 & 4,856 & 2,257 & 126,718 \\
\hline Females & 113,092 & 4,919 & 1,962 & 119,973 \\
\hline Sex Ratio & 106 & 99 & 115 & 106 \\
\hline
\end{tabular}




\section{The Prevalence of Bastardy}

The annual distribution of all Taiwanese births across the three categories of legitimacy used in the colonial records in various years is presented in Table 1. The Japanese colonial authorities required that all births in an area be recorded in the household (koseki) register maintained at the local police station. Compliance was enforced through a system of police supervision ard joint responsibility, an effective form of the traditional pao-chia system (see Chen, 1975).

Legitimate births included all those births to currently married women. While Barclay points out that the legitimacy of birth is thus largely determined by administrative fiat, and may have failed to include some marriages which had not been registered with the colonial authorities, I think that this objection to the use of these statistics is a relatively weak one (see Barclay, 1954a:241). ${ }^{4}$ The problem of marital definition occurs in almost all literate cultures, and tends to confound most studies of illegitimacy, particularly those which purport to chart changes over time (see Shorter, Knodel, and van de Walle, 1971: 380-382).

There are several reasons to believe that the household register data and the com-

"It is possible that because of a reliance on an administrative rather than a cultural definition of marriage the illegitimacy rates presented here are overstated. Nevertheless, Barclay presents no evidence that this was a serious problem in the data; if anything, the colonial statistics are remarkable for the high percentage of women who were considered "administratively married," usually at fairly young ages.

One researcher with extensive fieldwork experience and use of the household registers has pointed out that while underregistration of minor marriages was possible, the public festivities associated with major marriage and the usual rural practice of inviting the colonial police to the wedding make it unlikely that they were not recorded (A. Wolf, personal communication). mon perception of who was "married" in a Taiwanese community in this period did not vary greatly. While Taiwanese villagers tend to differ among themselves about the exact point in the marital negotiations the marriage actually begins (some feel it only begins with the recording of the event in the household register; see Gallin, 1966: 212 ), there is no question that a contractual relationship has been undertaken, and that the contract has a legal status (see Okamatsu, 1971:appendis, v-x). According to Okamatsu, even "brief ceremonies" of the common people were recognized by the nineteenth century Ch'ing dynasty provincial government, and there is no reason to believe that the Japanese colonial government made their stipulations any more stringent.

The major question centers on whether or not a sizeable minority of people married but failed to register the marriage with the Japanese authorities. While it is true that registration of marriages was not required during the Ch'ing dynasty (Okamatsu, 1971:appendix, vii), none of the published investigations of household registration materials from the Japanese colonial period by anthropologists indicates that underregistration was a serious problem.

For the Chinese, marriage is a religious ceremony, but it is a family-based one which requires neither church approval nor a church ceremony. In fact, the participation of Taoist "clergy" is largely extraneous, except insofar as it helps to ensure supernatural cooperation in a key event in the family life cycle (see Gallin, 1966:209). Religious groups have never had any legal power to forbid marriage, so that one of the major sources of definitional ambiguity does not complicate the Taiwanese case.

The colonial authorities allowed three types of unions to be registered as full marriages: major marriage (where the bride married into the groom's house), 
minor marriage (where the bride had previously been adopted into the groom's house as a "little daughter-in-law"), and uxorilocal marriage (where the groom married into the current household of the bride). The authorities did not permit the registration of unions with concubines as full marriages.

According to the Sasos, the Japanese colonial authorities did not want to encourage concubinage. But they had already decided that the $\mathrm{Ch}^{\prime}$ ing dynasty common law code, which legally recognized concubinage and certain forms of slavery, would be one legitimate form of common law in Taiwan for the Taiwanese (Saso and Saso, 1975:62). As a result, concubinage was recognized as a "quasimarriage," and the children resulting from such a match would have a right to share in the inheritance. But

\begin{abstract}
Since the quasi-spouse was not considered to be a legitimate spouse, in civil and criminal cases bigamy and adultery could not be considered as legal cases to be handled in court. In a series of legal decisions, the Japanese soon established the customary privileges of the concubine in her quasi-marriage, as reflected in the Koseki family registers. If a concubine decided to marry another man as a legitimate wife, divorce proceedings were unnecessary, nor could she be accused of adultery (Taiwan Supreme Court, 1905) or bigamy (Taiwan Supreme Court, 1917) (Saso and Saso, 1975:63).
\end{abstract}

Thus the consort of a concubine, like the father of an ordinary bastard, could not compel an exclusive sexual relationship with his partner. It can be argued that the minimum condition for a marital relation, at least in a male-dominated society like China's, is an enforceable contract for sexual exclusivity on the part of the woman. If so, then in Taiwan at least, concubinage was not a full form of marriage.

In some censuses, the Japanese listed concubines as a sub-category of married women. Thus in those years we have the number of concubines of various ages, as well as the numbers of married, nevermarried, widowed, and divorced women given in all the censuses.

The Japanese also registered all births in each year in one of three legitimacy categories: fully legitimate births, illegitimate births, and births to concubines. Births to concubines had a semi-legitimate status because such births were acknowledged by a father, even though there was no legal marriage contract between the parents.

In the analysis below, primary emphasis will be placed on the measurement and interpretation of "true" illegitimate births to women who were neither currently married nor concubines. The registered births of children to concubines will be excluded from the computation of all rates and ratios of illegitimacy in order to avoid the possibility of exaggerating the extent of illegitimacy by including births which may have seemed legitimate to some Taiwanese, even though the authorities disagreed.

Conceivably, illegitimate births include those births to concubines whose consorts refused to recognize paternity when the births were registered, even though the conventional reason for taking a concubine was to produce a male heir. (Despite this F.L.K. Hsu found considerable slippage between the ideal and the reality in West Town, Yunnan province; see Hsu, 1971: 105.)

If we examine the sex ratio at birth from 1915 on (see Table 1), we find that the sex ratio for legitimate births is either 105 or 106 , which is close to what is thought to be the normal distribution of births by sex for large human populations. ${ }^{5}$ However, the sex ratio of illegitimate births is consistently below this figure, indicating a

'It has been shown (Barclay, 1954a:242, fn.) that there was a tendency towards the underregistration of female stillbirths and neo-natal deaths, but this problem had largely been corrected by 1915 . As a result, the sex ratios at birth for different legitimacy categories in 1906 and 1910 may not be too reliable. 
probable underregistration of male births. Conversely, the sex ratios at birth for concubines' children are consistently higher than 105 , which shows that there was an overregistration of male births.

One possible explanation for these differences is that the consorts of concubines were more likely to acknowledge paternity of a male child than a female one. This would account for the overrepresentation of boys among concubines' births and their underrepresentation among illegitimate births. As was suggested in footnote 5 above, it seems unlikely that these differences in sex ratios at birth were the result of underregistration of early female infant deaths after 1915 .

Demographers are generally interested in the proportion of illegitimate births among all births. This proportion gives an indication of the social importance of bastardy, as well as the contribution of illegitimacy to the overall rates of fertility.

TABLE 2. DISTRIBUTION OF TAIWANESE BIRTHS BY LEGITIMACY STATUS, TAIWAN, 1906-1940, SELECTED YEARS, IN PERCENT.

\begin{tabular}{|c|c|c|c|c|}
\hline Year & $\begin{array}{l}\text { Legiti- } \\
\text { mate } \\
\text { Births } \\
\end{array}$ & $\begin{array}{c}\text { Illegiti- } \\
\text { mate } \\
\text { Births } \\
\end{array}$ & $\begin{array}{c}\text { Births to } \\
\text { Concu- } \\
\text { bines }\end{array}$ & Total \\
\hline 1906 & 96.8 & 2.3 & 0.9 & 100.0 \\
\hline 1910 & 96.3 & 2.7 & 1.0 & 100.0 \\
\hline 1915 & 96.1 & 2.9 & 1.0 & 100.0 \\
\hline 1920 & 95.0 & 4.0 & 1.0 & 100.0 \\
\hline 1925 & 94.8 & 4.2 & 1.0 & 100.0 \\
\hline 1930 & 94.8 & 4.1 & 1.1 & 100.0 \\
\hline 1935 & 94.4 & 4.4 & 1.1 & 100.0 \\
\hline 1940 & 94.3 & 4.0 & 1.7 & 100.0 \\
\hline
\end{tabular}

Source of Data: Bureau of Accounting and Statistics, 1946:216-217.

The simplest of these measures is the illegitimacy ratio, which is illegitimate births expressed as a percentage of all births. This ratio, together with its equivalent, the "concubinage ratio," is given for various years in Table 2 . Apparently there was a gradual rise in the illegitimacy ratio until 1935, when illegitimate births comprised 4.4 percent of all births. The concubinage ratio hovered close to one percent of all births for most of the period. I do not have any ready answer for why there was a rather sharp upsurge in the concubinage ratio (1.7 percent) in 1940 .

This gradual increase in the illegitimacy ratio is over-shadowed by the magnitude of its areal variation. While figures for the lower-level units, the districts and townships, do not appear to be extant, an examination of the prefectural statistics on illegitimacy shows that there appear to have been different cultural patterns or adaptations of illegitimacy, and that these patterns were relatively stable over time.

The colonial government began recording illegitimate births by prefecture in 1920. A comparison of the illegitimacy ratios for prefectures in 1920 and 1935 shows the stability of these social patterns over the fifteen-year period (see Table 3 ).

As in previous analyses of Taiwanese fertility (e.g., Barclay, 1954a:232), we will place primary emphasis on the patterns of fertility in the western coastal plains where most of the Taiwanese lived. The two East Coast prefectures had large proportions of aborigines in their populations and much lower ratios of people to arable land, and the Japanese colonial authorities excluded the central mountain aborigine preserve from the statistics and census system.

There are considerable differences in the illegitimacy ratios of the West Coast prefectures: Taipei's ratio hovers at about 9 percent, while Taichung's rate is only about 2 percent in both 1920 and 1938 . While economists and anthropologists have identified certain regional differences in economic and family organization and dominant crop type, these variations do not appear to suggest any immediately obvious explanations for differences in the illegitimacy ratios. 
TABLE 3. ILLEGITIMACY RATIOS, TAIWANESE PREFECTURES, 1920 AND 1935.

\begin{tabular}{|c|c|c|c|c|c|c|}
\hline \multirow[b]{2}{*}{ Prefecture } & \multicolumn{3}{|c|}{1920} & \multicolumn{3}{|c|}{1935} \\
\hline & $\begin{array}{l}\text { Total } \\
\text { Births } \\
\end{array}$ & $\begin{array}{l}\text { Illegitimate } \\
\text { Births }\end{array}$ & $\begin{array}{c}\text { Ratio } \\
\text { (Percent) } \\
\end{array}$ & $\begin{array}{c}\text { Total } \\
\text { Births } \\
\end{array}$ & $\begin{array}{c}\text { Illegitimate } \\
\text { Births } \\
\end{array}$ & $\begin{array}{c}\text { Ratio } \\
\text { (Percent) }\end{array}$ \\
\hline Taipei & 27,849 & 2,340 & 8.40 & 37,188 & 3,366 & 9.05 \\
\hline Hsinchu & 23,487 & 1,284 & 5.47 & 30,613 & 1,283 & 4.19 \\
\hline Taichung & 34,440 & 693 & 2.01 & 53,307 & 1,003 & 1.88 \\
\hline Tainan & 39,978 & 895 & 2.24 & 63,228 & 1,841 & 2.91 \\
\hline Kaohsiung & 24,085 & 1,123 & 4.66 & 32,804 & 1,588 & 4.84 \\
\hline Taitung & 1,508 & 114 & 7.56 & 2,394 & 220 & 9.19 \\
\hline Hualien & 2,029 & 315 & 15.52 & 3,646 & 541 & 14.84 \\
\hline Penghu* & - & - & - & 2,800 & 209 & 7.46 \\
\hline Total & 158,688 & 6,972 & 4.39 & 225,980 & 10,021 & 4.43 \\
\hline
\end{tabular}

Note: While the present analysis centers on the west coast prefectures, Taitung and Hualien prefectures were included here to show that their illegitimacy ratios were relatively stable over time as well. The reasons for the high illegitimacy ratios among the populations of these two east coast prefectures are not clear, but they may be related to the fact that both were still "frontier" areas during the colonial period.

*Included in Kaohsiung Prefecture until 1926.

One possible explanation for these differences is that they reflect the more developed urbanization in some prefectures. Since urban areas often have surpluses of young, unmarried men or women, hypotheses about the effects of urban living on the levels of illegitimate fertility often use variations in the sex ratio. As Knodel and Hochstadt point out, there are two contradictory arguments about the influence of the sex ratio on illegitimacy. One theory says that a surplus of women at marriageable ages will give males an advantage in sexual bargaining, and the result will be more illegitimate births. The other argument holds that a scarcity of women will subject the few available unmarried women to a constant hounding by men, which will lead them to grant favors and inflate the illegitimate birth rate (see Knodel and Hochstadt, 1976:28). ${ }^{6}$

The illegitimacy ratios of the urban and rural sections of West Coast prefectures in

${ }^{6}$ It has also been suggested that a severe shortage of women would encourage Taiwanese parents to sell their daughters into prostitution, which would tend to inflate the illegitimacy ratio (N. Diamond, personal communication),
1935 shown in Table 4 indicate that the ratios are variable in both areas, but that the urban sections of prefectures have consistently higher ratios than the rural regions. Thus, illegitimacy appears to be linked to urban residence.

Nevertheless, the illegitimacy ratio says nothing about the rate of bastardy among currently unmarried women. It is possible that the illegitimacy ratio is strongly affected by the larger proportion of unmarried women in cities, and that the actual fertility of these unmarried urban women may actually be below that of their rural counterparts. Another demographic measure of the rate of illegitimate births must be computed if we are to settle this question.

These are a variety of ways of measuring the rate of illegitimate fertility. I have chosen to compute Coale's $I_{h}$, which is "an illegitimate fertility rate (number of illegitimate births $/ 1,000$ unmarried women of childbearing age) which has been 'in. directly standardized' for the age distribution of the unmarried women (this is important because of age differences in fertility)" (Shorter, Knodel, and van de Walle, 1971:379). The $I_{h}$ is the most 
TABLE 4. ILLEGITIMACY RATIOS FOR URBAN AND RURAL SECTIONS OF PREFECTURES, TAIWAN, 1935.

\begin{tabular}{|c|c|c|c|}
\hline Area & $\begin{array}{c}\text { Total } \\
\text { Prefecture }\end{array}$ & $\begin{array}{l}\text { Urban } \\
\text { Area }\end{array}$ & $\begin{array}{l}\text { Rural } \\
\text { Area } \\
\end{array}$ \\
\hline Taipei & 9.05 & 14.25 & 7.23 \\
\hline Hsinchu & 4.19 & 6.01 & 4.07 \\
\hline Taichung & 1.88 & 5.37 & 1.56 \\
\hline Tainan & 2.91 & 5.71 & 2.58 \\
\hline Kaohsiung & 4.84 & 6.77 & 4.39 \\
\hline Taiwan, Total & 4.43 & 8.85 & 3.82 \\
\hline
\end{tabular}

Note: The urban areas of the prefectures included: Taipei Prefecture: Taipei City, Chilung City; Hsinchu Prefecture: Hsinchu City; Taichung Prefecture: Taichung City, Changhua City; Tainan Prefecture: Tainan City, Chiayi City; Kaohsiung Prefecture: Kaohsiung City, Pingtung City. All other sections of each prefecture were included in the rural area.

sophisticated measure that can be computed from the available data, and it is a useful one because it measures non-marital fertility against an objective standard. Since Coale's Ih measure has been widely used in European historical demographic research, it also permits us to compare Taiwan with that and other areas of the world.

The $I_{h}$ is superior to the illegitimacy ratio for the determination of the actual probability of births to unmarried women between the ages of 15 and 49 years. In Table 5, the levels of the $I_{h}$, the illegitimacy ratio, and the sex ratio of currently unmarried men 15 to 34 years to unmarried women of the same ages are given.

First, it should be noted that while the values of $I_{h}$ for urban areas of prefectures are still higher than those for their respec-

'The four measures of fertility developed by Ansley Coale (i.e., $I_{f}, I_{m}, I_{g}$, and $I_{h}$ ) are useful tools in comparative historical demographic research (see Coale, 1969, for definitions of these measures). Estimates of these measures for Taiwan at various dates can be found in Barclay et al. 1976:616, and in Barrett, 1978a:171. For what is probably the most accurate estimate of these measures for Taiwan, see Freedman and Casterline, 1979.
TABLE 5. SEX RATIOS, ILLEGITIMACY RATIOS, AND THE INDEX OF ILLEGITIMACY $\left(I_{h}\right)$ FOR URBAN AND RURAL SECTIONS OF PREFECTURES, TAIWAN, 1935.

\begin{tabular}{|c|c|c|c|}
\hline Area ${ }^{a}$ & Sex Ratiob & $I_{h}$ & $\begin{array}{l}\text { Illegitimacy } \\
\text { Ratio }\end{array}$ \\
\hline \multicolumn{4}{|l|}{ Taipei } \\
\hline Urban & 160.1 & .2131 & 14.25 \\
\hline Rural & 246.0 & .1862 & 7.23 \\
\hline \multicolumn{4}{|l|}{ Hsinchu } \\
\hline Urban & 151.5 & .1169 & 6.01 \\
\hline Rural & 167.8 & .1151 & 4.07 \\
\hline \multicolumn{4}{|l|}{ Taichung } \\
\hline Urban & 175.8 & .1145 & 5.37 \\
\hline Rural & 163.3 & .0405 & 1.56 \\
\hline \multicolumn{4}{|l|}{ Tainan } \\
\hline Urban & 173.3 & .1013 & 5.71 \\
\hline Rural & 176.4 & .0781 & 2.58 \\
\hline \multicolumn{4}{|l|}{ Kaohsiung } \\
\hline Urban & 193.9 & .1593 & 6.77 \\
\hline Rural & 158.2 & .1356 & 4.39 \\
\hline $\begin{array}{l}\text { All West Coast } \\
\text { Urban Areas }\end{array}$ & 169.9 & .1555 & 8.85 \\
\hline $\begin{array}{l}\text { All West Coast } \\
\text { Rural Areas }\end{array}$ & 177.0 & .1001 & 3.82 \\
\hline Taiwan, Total & 173.8 & .1078 & 4.43 \\
\hline
\end{tabular}

a Note: For the specification of urban and rural areas of these prefectures, see Table 4.

$b_{\text {This }}$ sex ratio is the ratio of all currently unmarried men aged 15-34 years to all currently unmarried women aged 15-34 years in each area.

tive rural regions, the differences are much smaller than when the illegitimacy ratios were used. This indicates that the greater incidence of illegitimate births in cities is partially due to the greater number of unmarried women in those areas. Moreover, some rural regions of prefectures, such as Taipei or Kaohsiung, have higher indices of illegitimacy $\left(I_{h}\right)$ than some urban areas of prefectures, such as those of Hsinchu, Taichung, and Tainan prefectures. This fact shows that differential illegitimate fertility is unrelated to the variations in the degree of urbanization between prefectures.

The comparison of the sex ratios of unmarried men to women between the ages 
of 15 and 34 years and either measure of illegitimate fertility does not provide much support for either of the theories mentioned above. Neither the scarcity. nor the abundance of unmarried women appears to have much relation to the current level of bastardy. Of course, it is possible that the kinds of social interactions implied in these theories occurs within a much smaller area than the prefecture. If this is the case, then these data should not be taken too seriously. However, since the colonial authorities do not appear to have collected data on the legitimacy of birth for areas below the prefectural and city level, it may be necessary for future researchers to attack this question through the reconstruction of household registers rather than through the use of census and vital statistics data.

\section{Illegitimacy Ratios of Hokkiens and Hakkas}

The Japanese divided the "Taiwanese" population into three categories: those of Fukien origin (Hokkiens), those of Kwangtung origin (Hakkas), and the lowland and highland aborigines. ${ }^{8}$ While there are some ethnic or linguistic differences within the two major Chinese groups, the Hokkiens and the Hakkas, one hypothesis about differences in illegitimacy is that it reflects differences in culture between these two major groups. Since the 1925 and 1935 census and vital statistics volumes provide data on marital status and ages of women and legitimacy status of births by ethnic group in each prefecture, it is possible to investigate the influence of

${ }^{8}$ The most complete data on the ethnic back. ground of the Taiwanese (and perhaps of any Chinese area) appear in a special 1926 census of ethnic background conducted by the colonial authorities. An analysis of the results of this census and estimates of the degree of spatial segregation of the twelve ethnic and dialect groups can be found in Barrett, 1978a: $227-273$. ethnicity on the illegitimacy ratio (see Tables 6 and 7, and Figure 1).

While the Hokkiens and Hakkas did have minor difference in marriage patterns in this period (see Barclay, 1954a:231-233), the data show that ethnic differences had little effect on illegitimacy ratios. Again, region seems to be a more important determinant of illegitimacy than ethnicity; the ethnic groups show marked differences only in areas where the total number of births to women of one of the ethnic groups were less than one thousand. In such cases we might well expect some instability in the ratios, due to the small number of cases used in their computation.

It has been argued that Hakka women had a higher status relative to that of women in other southern Chinese ethnic groups. Hakka women did not bind their feet, and there may have been less occupational segregation (especially in farming) in Hakka communities. However, the greater "freedom," if that is the inference one wishes to put on such cultural differences, did not appear to have a marked effect on their illegitimacy ratios.

\section{Non-marital Age Specific Fertility Rates}

One of the drawbacks of working with data on births in colonial Taiwan is the unavailability of specific information on the ages of mothers. Researchers have tried to get around this problem by using age specific fertility rates of countries such as Japan in computing plausible estimates of the Gross Reproduction Rate (see Barclay, 1954a: 246). But the drawbacks of this kind of solution are fairly obvious. The recent debate among historical demographers about the prevalence of "natural fertility" among premodern European and Asian populations has made this lacuna even more regrettable. ${ }^{9}$

${ }^{9}$ The recent collections of studies in the volumes edited by Lee (1977) and Tilly (1978) provide many 
TABLE 6. HOKKIEN ILLEGITIMACY RATIOS BY PREFECTURE, TAIWAN, 1925 AND 1935.

\begin{tabular}{|c|c|c|c|c|}
\hline \multirow[b]{2}{*}{ Prefecture } & \multicolumn{2}{|r|}{1925} & \multicolumn{2}{|c|}{1935} \\
\hline & Hokkien & All Taiwanese & Hokkien & All Taiwanese \\
\hline Taipei & 8.38 & 8.40 & 9.05 & 9.05 \\
\hline Hsinchu & 6.43 & 5.47 & 5.58 & 4.19 \\
\hline Taichung & 1.54 & 2.01 & 1.64 & 1.88 \\
\hline Tainan & 2.19 & 2.24 & 2.84 & 2.91 \\
\hline Kaohsiung & 4.38 & 4.66 & 4.61 & 4.84 \\
\hline Taitung & 8.11 & 7.21 & 8.51 & 9.19 \\
\hline Hualien & 15.01 & 15.52 & 13.69 & 14.84 \\
\hline Penghu* & - & - & 7.46 & 7.46 \\
\hline Taiwan, Total & 4.01 & 4.39 & 4.31 & 4.43 \\
\hline
\end{tabular}

Note: The "All Taiwanese" category includes Hakkas, Hokkiens, other Chinese, lowland aborigines, and highland aborigines not under separate Japanese police administration in the mountain reserves.

*Part of Kaohsiung Prefecture until 1926.

TABLE 7. HAKKA ILLEGITIMACY RATIOS BY PREFECTURE, TAIWAN, 1925 AND 1935.

\begin{tabular}{|c|c|c|c|c|}
\hline \multirow[b]{2}{*}{ Prefecture } & \multicolumn{2}{|r|}{1925} & \multicolumn{2}{|c|}{1935} \\
\hline & Hakkas & All Taiwanese & Hakkas & All Taiwanese \\
\hline Taipei & $10.82^{*}$ & 8.40 & $8.53^{*}$ & 9.05 \\
\hline Hsinchu & 4.68 & 5.47 & 3.34 & 4.19 \\
\hline Taichung & 3.61 & 2.01 & 3.91 & 1.88 \\
\hline Tainan & $9.05^{*}$ & 2.24 & $9.02^{*}$ & 2.91 \\
\hline Kaohsiung & 3.23 & 4.66 & 4.37 & 4.84 \\
\hline Taitung & $14.58^{*}$ & 7.21 & $7.39 *$ & 9.19 \\
\hline Hualien & $12.93 *$ & 15.52 & $9.68^{*}$ & 14.84 \\
\hline Penghu** & - & - & - & 7.46 \\
\hline Taiwan, Total & 4.52 & 4.39 & 4.00 & 4.43 \\
\hline
\end{tabular}

Note: The "All Taiwanese" category includes Hakkas, Hokkiens, other Chinese, lowland aborigines, and highland aborigines not under separate Japanese police administration in the mountain reserves.

*These prefectures had fewer than 1,000 Hakka births per year; as a result, some of the illegitimacy ratios may be unstable.

In 1935, there were no Hakka births in Penghu Prefecture.

**Part of Kaohsiung Prefecture until 1926.

In the course of working in the stacks of the Orientalia Division of the Library of Congress in Washington, D.C., I came across a Taiwanese demographic report which had apparently escaped the notice of either George Barclay or Irene Taeuber, who had also conducted a fairly thorough

comparative data on natural fertility in many areas. In addition, Henry's (1960) reworking of Chi-hsien Tuan's data (1958) shows how the natural fertility hypothesis might be applied in a Taiwanese context. survey of the colonial demographic resources (see Taeuber, 1961). ${ }^{10}$ This report

${ }^{10}$ This slim volume (Government General of Taiwan, 1943) was uncatalogued and misfiled in the Manchurian section of the library's Japanese-language holdings. As far as I know, it is unavailable at either the Taiwan Branch Library of the National Central Library or at the Main Library of National Taiwan University (both are in Taipei, Taiwan), the two other main repositories of published Japanese reports on colonial Taiwan. 
FIGURE 1. ILLEGITIMACY RATIOS OF MAJOR CHINESE ETHNIC GROUPS BY PREFECTURE, TAIWAN, 1925 AND 1935.
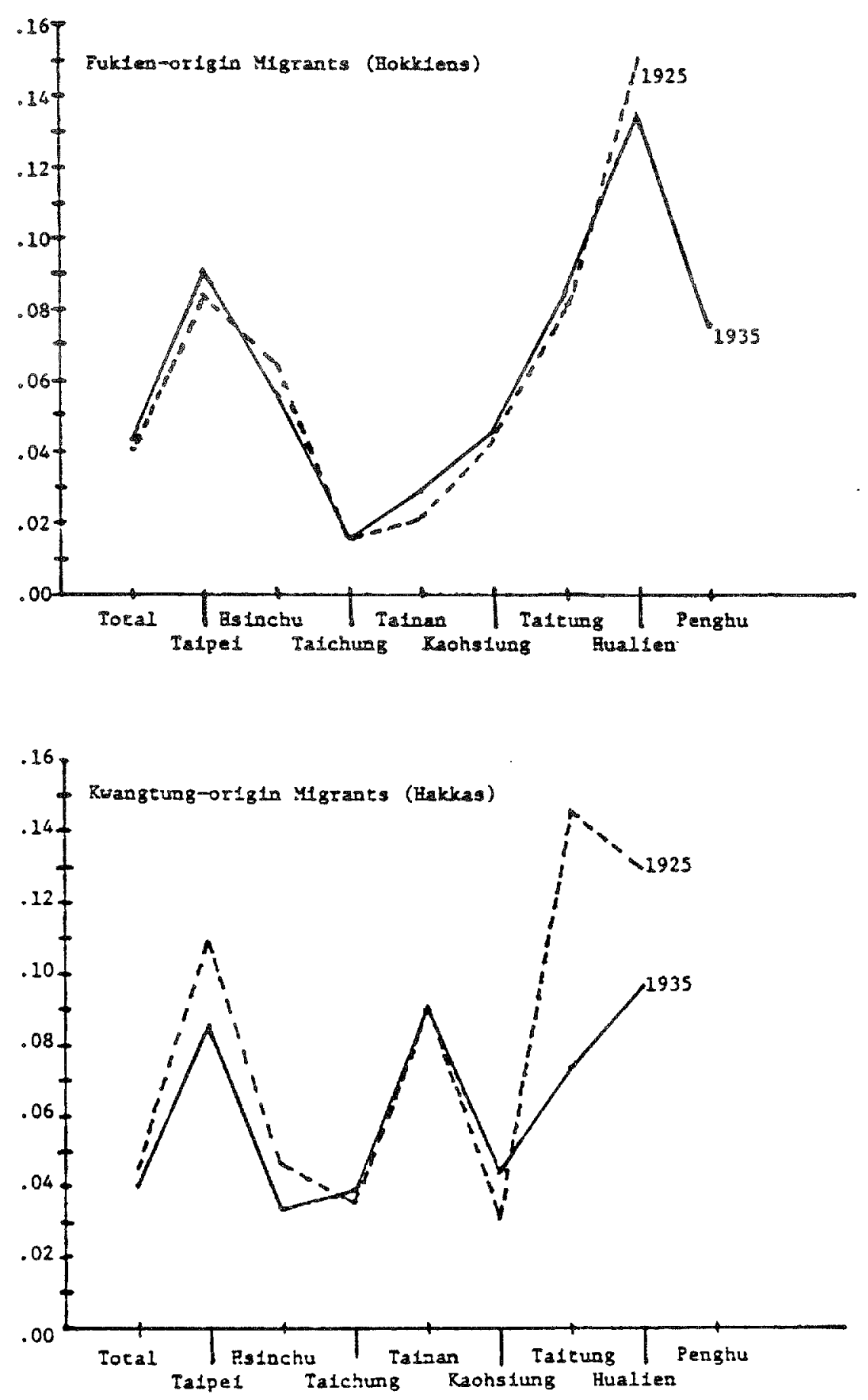
provided the following information, by prefecture and urban and rural areas, on all Taiwanese and Japanese births on the island in 1941: 1) age of mother and father for all legitimate births; 2) age of father for all births to concubines; and 3) age of mother for all illegitimate births. In addition, the report provided the same information on ages of parents by marital status for all still-births.

Why the Japanese went to such lengths to classify all of the approximately 240,000 births to Taiwanese in 1941 by age of parents is not clear. They never published any analysis of this study, and it has never been used by later researchers. What makes this study of considerable importance is the fact that when these data on births are combined with the census data of 1940 , it is possible to compute marital and non-marital age specific birth rates for single years of age. ${ }^{11}$

The 1940 census results provide the number of women at single years of age for each prefecture in October, 1940 (see Bureau of Accounting and Statistics, 1953:4045). In addition, the 1940 census results give the marital status of women by fiveyear age categories for each prefecture; and a good estimate of the distribution of marital status by single years, within these fiveyear age categories, can be obtained from the more extensive 1935 census (Government General of Taiwan, 1937).

However, before these marital proportions could be applied to the number of women at each age, it was necessary to "age" the October, 1940 population about eight months so that all age specific rates would apply to the 1941 mid-year population of women (see Shryock and Siegel, 1973:472-485). Since single-year age specific death data were available from the annual vital statistics reports, the actual

"The data on marital age specific fertility rates will be presented in a separate report. shrinkage in each single-year cohort over the eight-month period could be estimated with a high degree of accuracy (see Government General of Taiwan, 1942:54-66).

After the deaths for each single-year cohort were subtracted, the survivors were apportioned among marital statuses ac-

TABLE 8. AGE-SPECIFIC FERTILITY RATES FOR ALL WOMEN, ALL CURRENTLY MARRIED WOMEN, AND ALL, CURRENTLY UNMARRIED WOMEN, TAIWANESE, 1941.

\begin{tabular}{|c|c|c|c|}
\hline Age & $\begin{array}{l}\text { Total } \\
\text { ASFR } \\
\end{array}$ & $\begin{array}{c}\text { Marital } \\
\text { ASFR } \\
\end{array}$ & $\begin{array}{c}\text { Non-Marital } \\
\text { ASFR } \\
\end{array}$ \\
\hline 15 & 31.1 & 157.1 & 3.4 \\
\hline 16 & 79.3 & 191.6 & 7.2 \\
\hline 17 & 132.1 & 258.3 & 13.9 \\
\hline 18 & 207.4 & 305.7 & 20.8 \\
\hline 19 & 247.5 & 339.0 & 29.5 \\
\hline 20 & 270.1 & 363.6 & 40.8 \\
\hline 21 & 277.0 & 358.8 & 56.7 \\
\hline 22 & 309.4 & 350.8 & 81.8 \\
\hline 23 & 305.3 & 334.5 & 95.5 \\
\hline 24 & 287.4 & 328.9 & 123.1 \\
\hline 25 & 316.0 & 322.1 & 118.7 \\
\hline 26 & 287.5 & 307.4 & 122.5 \\
\hline 27 & 277.9 & 304.4 & 110.4 \\
\hline 28 & 271.7 & 291.8 & 98.5 \\
\hline 29 & 269.2 & 289.9 & 93.9 \\
\hline 30 & 246.3 & 280.8 & 87.7 \\
\hline 31 & 248.8 & 279.8 & 80.0 \\
\hline 32 & 241.6 & 272.1 & 82.6 \\
\hline 33 & 227.5 & 264.8 & 68.3 \\
\hline 34 & 224.5 & 245.6 & 58.8 \\
\hline 35 & 207.6 & 246.6 & 55.3 \\
\hline 36 & 164.0 & 222.0 & 46.4 \\
\hline 37 & 184.2 & 209.4 & 38.9 \\
\hline 38 & 163.2 & 197.1 & 38.2 \\
\hline 39 & 129.8 & 183.2 & 25.6 \\
\hline 40 & 115.4 & 156.6 & 20.4 \\
\hline 41 & 84.5 & 130.8 & 18.6 \\
\hline 42 & 66.2 & 103.1 & 11.8 \\
\hline 43 & 34.0 & 77.8 & 7.7 \\
\hline 44 & 21.0 & 47.7 & 3.5 \\
\hline 45 & 10.0 & 27.2 & 2.8 \\
\hline 46 & 7.1 & 12.6 & 0.8 \\
\hline 47 & 3.0 & 10.1 & 0.5 \\
\hline 48 & 3.3 & 4.1 & 0.0 \\
\hline 49 & 2.8 & 4.6 & 0.2 \\
\hline 50 & 4.6 & 4.5 & 0.0 \\
\hline
\end{tabular}


cording to the estimates computed from the 1935 and 1940 censuses. (The assumption was made that the death rates for women of the same age but different marital statuses were the same.) The never-married, currently divorced, and currently widowed women in each age category were grouped together to form the currently unmarried category.

Table 8 shows the age specific fertility rates for single years of age for the currently married and currently unmarried groups of women. In the former case, the rate was computed by dividing the total number of legitimate births by the number of currently married women at each age; in the latter case, the bastard births were divided by the number of unmarried women. It is important to note that because no age specific data on the distribution of concubines' births were available, these births were excluded from Table 8 and Figure $2 .^{12}$

"As can be seen from Table 2, births to concu. bines comprised about one percent of all births in most years. If these births were added into the numerators of the age specific fertility formulac, it is logical to assume that marital age specific rates would increase little more than one percent. While I suspect that births to concubines tended to be concentrated at younger ages than births to all married women, these data are insufficient to test this hypotinesis.

FIGURE 2. MARITAL AND NON-MARITAL AGE-SPECIFIC FERTILITY RATES, TAIWANESE WOMEN, 1941.

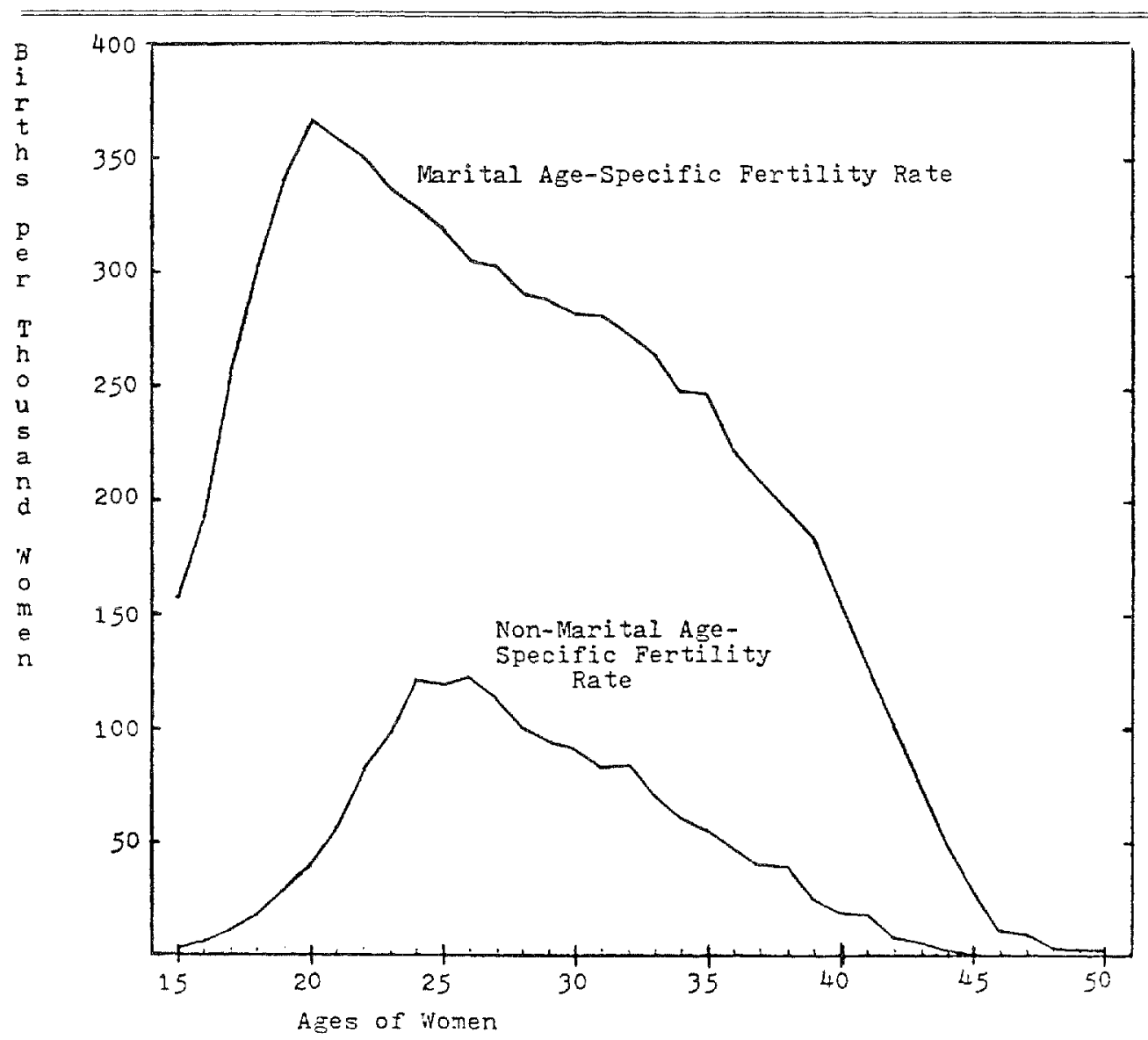


FIGURE 3. NON-MARITAL AGE-SPECIFIC FERTILITY RATES, WEST COAST PREFECTURES AND WHOLE ISLAND, TAIWANESE POPULATION OF TAIWAN, 1941.

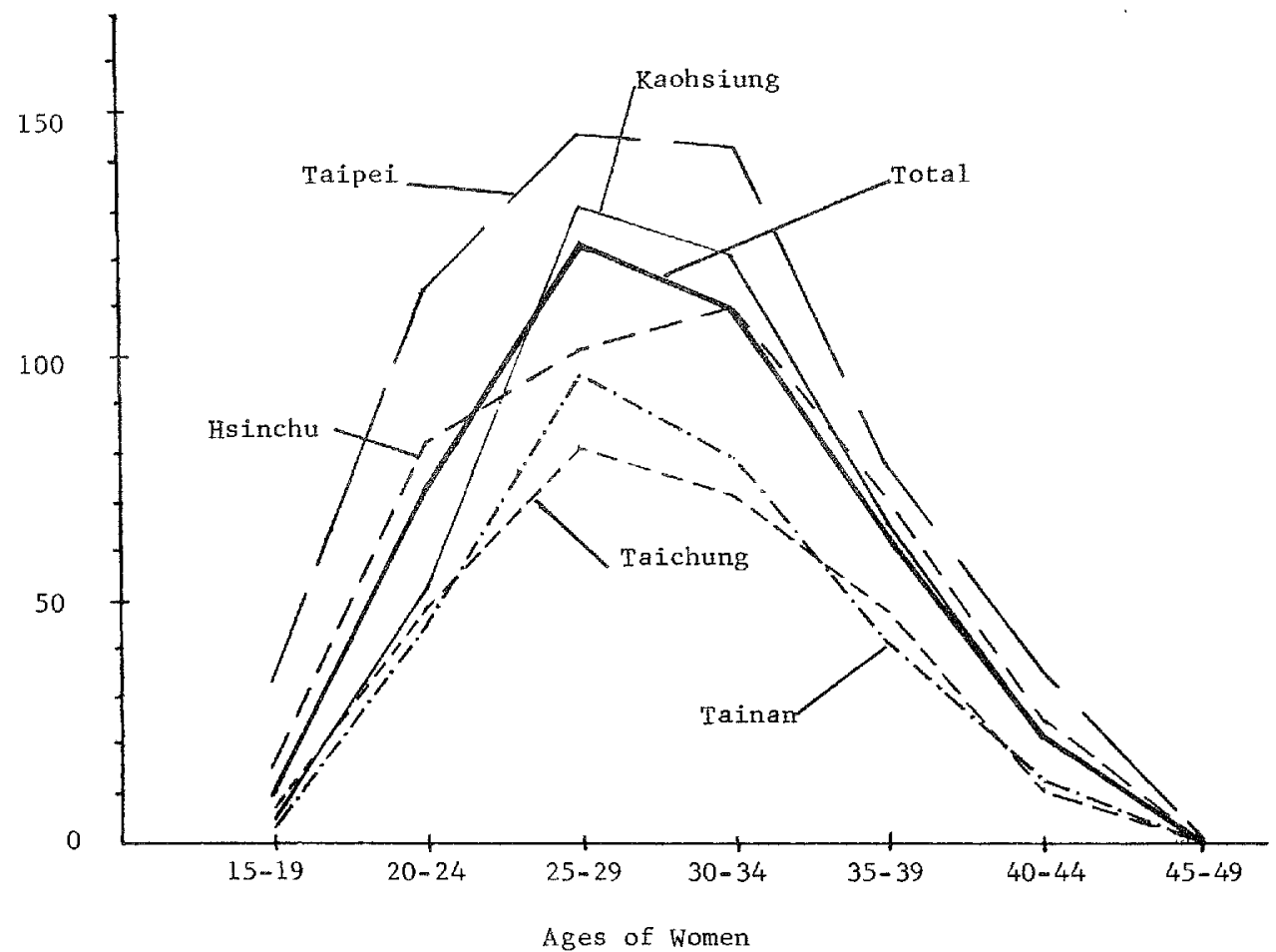

Table 8 and Figure 2 show that the age specific fertility curve for married women peaks at age 20 and declines steadily thereafter. While the non-marital fertility curve is at a much lower level throughout the fecund years, it increases until about age 24 , declines slowly until age 32 , and then drops off more quickly.

The 1941 non-marital age specific fertility rate, like the $1935 I_{h}$ measure, shows a fair amount of variation between prefectures (see Figure 3). While the level of i1legitimacy varies, there appears to be a general similarity in the shape of the distribution across ages. The only major exception here appears to be Hsinchu Prefecture, where non-marital fertility peaks late, at ages 30 to 34 years. I have no easy answer for why Hsinchu exhibits this deviant pattern. It is conceivable that it is related to the large proportion of Hakkas in that prefecture, but as evident in Tables 6 and 7 , the Hakkas do not appear to differ in their overall levels of non-marital fertility. Since these 1941 data were not classified by ethnic background, it is not possible to provide a conclusive answer to this question.

While it is possible to specify the ages of mothers of illegitimate children and their fertility rates, the available data do not allow us to determine whether these children were born to never-married, divorced, or widowed women. Any meaningful evaluation of the social significance of bastardy 
in Taiwanese communities must be linked to the issue of the previous marital status of these mothers. ${ }^{13}$

From his examination and reconstruction of the household registers from Haishan District in the southern Taipei prefecture, Arthur Wolf has concluded:

Despite an early marrying age and a puritanical attitude towards premarital sexual relations in our six districts, 12.3 percent of all women raised there bore at least one illegitimate child [before they married]. But this does not mean that most young women experimented with sex before marriage. Since the majority of those who bore illegitimate children were the daughters (or adopted daughters) of people who were dependent on them because they had no sons, most of these children were probably the fruits of prostitution (Wolf, 1975: 102).

${ }^{13}$ Let me stress that what I am referring to here are the rates of marital or non-marital fertility (i.e. per 1,000 women in the category), not to the actua frequency of occurrence. The frequency distribution of legitimate and illegitimate births by age of mother in 1941 was as follows:

FREQUENCY DISTRIBUTION OF LEGITIMATE AND ILLEGITIMATE BIRTHS BY AGE OF MOTHER, 15-49 YEARS, IN FIVE-YEAR INTERVALS, TAIWAN, 1941.

\begin{tabular}{|c|c|c|c|c|}
\hline \multirow{2}{*}{$\begin{array}{l}\text { Age } \\
\text { Group } \\
\end{array}$} & \multicolumn{2}{|c|}{$\begin{array}{c}\text { Legitimate } \\
\text { Births }\end{array}$} & \multicolumn{2}{|c|}{$\begin{array}{c}\text { Illegitimate } \\
\text { Births }\end{array}$} \\
\hline & Number & Percent & Number & Percent \\
\hline $15-19$ & 22,266 & 9.79 & 2,389 & 23.43 \\
\hline $20-24$ & 63,031 & 27.73 & 2,882 & 28.26 \\
\hline $25-29$ & 57,754 & 25.40 & 1,897 & 18.60 \\
\hline $30-34$ & 44,820 & 19.72 & 1,494 & 14.65 \\
\hline $35-39$ & 27,924 & 12.28 & 1,055 & 10.35 \\
\hline $40-44$ & 10,569 & 4.65 & 443 & 4.34 \\
\hline $45-49$ & 974 & 0.43 & 38 & 0.37 \\
\hline Total & 227,338 & 100.00 & 10,198 & 100.00 \\
\hline
\end{tabular}

Note: As before, births to concubines, which totaled 4,360, were not included in this table.

Thus if we look at the actual frequencies, we find that illegitimate births are common to women in the 15-19 year age group (23.43 percent of all illegitimate births as opposed to 9.79 percent of all legitimate births). Nevertheless, the large proportion of unmarried women in that age group leads to low rates of nonmarital fertility.
One possible argument about the prevalence of bastardy in Taiwan is its high incidence among prostitutes, but its relative infrequence among the general population of women. The Japanese colonial authorities collected information on the occupation of women as a part of the census investigations, and also listed the occupational status of the mothers of illegitimate children from the early 1920s until 1942. Yet neither set of statistics specifies prostitutes. Further, Barclay says that the standards of classification used in assigning births to occupational groups differed from those used in the census. ${ }^{14}$

If we are willing, however, to approach this question of the marital status of mothers of bastards with another definition, it may be possible to shed some light on the question. Suppose the Confucian ethics did guide the behavior of most women, but that there was an "underclass" of servants and prostitutes who did not follow these normis, even though today the use of earnings from prostitution to support one's aged parents is still recognized as a form of filial piety in Taiwan.

Further, let us suppose that none of these uriderclass women were either currently married or widowed. This leaves us with two models: 1) all widows and divorcees are chaste, but never-married women are at risk of illegitimate births; and 2) all widows are chaste, but divorcees and nevermarried women are at risk of illegitimate

${ }^{14}$ See Barclay, 1954a:241. Throughout his work, Barclay rejects the use of the colonial data on the employment of women as a reliable source of information (Barclay, 1954a:73-101). Some anthropological evidence, however, suggests that the colonial data on employment of women may be more accurate than that collected more recently (sce Barrett, 1978a:390, fn). The many available data on historical trends in employment in Taiwan have received only a very superficial treatment by labor economists and sociologists, and the linkages between employment and marital or non-marital fertility have not been explored in any systematic fashion. 
births. Either model could be a reasonable approximation of the conditions of an idealized Confucian society.

From the 1935 and 1940 census data described above, good estimates of the 1941 mid-year populations of women at different marital statuses and five-year age categories can be obtained. Since we know the number of births to mothers of various ages in 1941, it is possible to specify the age specific fertility rates which would be implied by each of these models (see Table 9).

One way of evaluating the plausibility of each of these models is to compare the age specific fertility rates which each would generate with the actual marital and nonmarital age specific fertility rates presented earlier (non-marital age specific rates would include widows as well as divorcees and never-married women). As a general rule, one would not expect that either prostitutes or those involved in casual non-marital liaisons would have a higher birth rate than married women in a traditional society like Taiwan. However, one can see that in both models the age specific fertility rates of older unmarried women actually exceed those of married women. The birth rates at older ages implied by both models are particularly unbelievable.
What does this exercise prove? An inescapable conclusion is that at least some of the illegitimate fertility of unmarried women was due to non-marital births to widows, particularly at age thirty and over. There are simply too few never-married or currently divorced women at those ages to account for the relatively large number of illegitimate births.

This finding, however, does not exclude the possibility that most of the illegitimate births were to prostitutes. It is possible that some widows drifted into prostitution. But the usual route of recruitment into prostitution at this time was the apprenticing or outright sale of unmarried girls by their parents or others having legal authority over them. While few data exist on this topic, I would guess that the proportion of older widows engaged in prostitution was probably quite small.

It is doubtful if future research can squeeze out much more information on the marital background of the parents of bastards from the vital statistics and census data. The evidence does suggest sizeable numbers of divorcees and widows bearing illegitimate children; the age distribution of mothers suggests that these post-marital or inter-marital births were not necessarily the fruits of prostitutes. Fresh insights await researchers willing to devote the time

TABLE 9. TWO HYPOTHETICAL NON-MARITAL AGE-SPECIFIC FERTILITY RATES, AND THE ACTUAL NON-MARITAL AND MARITAL AGE-SPECIFIC FERTILITY RATES, TAIWAN, 1941.

\begin{tabular}{lccccc}
\hline & \multicolumn{2}{c}{ Non-Marital ASFRs If } & \multicolumn{2}{c}{ Actual ASFRs } \\
\cline { 2 - 3 } Ages & $\begin{array}{c}\text { Only Single Women } \\
\text { Were at Risk } \\
\text { (Model I) }\end{array}$ & $\begin{array}{c}\text { Single and Divorced Women } \\
\text { Were at Risk } \\
\text { (Model II) }\end{array}$ & $\begin{array}{c}\text { Non-Marital } \\
\text { ASFRs }\end{array}$ & $\begin{array}{c}\text { Marital } \\
\text { ASFRs }\end{array}$ \\
\cline { 2 - 3 } $20-24$ & 13 & 13 & & 12 & 283 \\
$25-29$ & 82 & 78 & 73 & 340 \\
$30-34$ & 227 & 192 & 123 & 304 \\
$35-39$ & 501 & 303 & 109 & 269 \\
$40-44$ & 606 & 322 & 63 & 215 \\
$45-49$ & 440 & 197 & 22 & 107 \\
\hline
\end{tabular}


FIGURE 4. COALE'S INDEX OF NON-MARITAL FERTILITY IN TAIWAN AND IN SELECTED EUROPEAN COUNTRIES, 1840-1960.

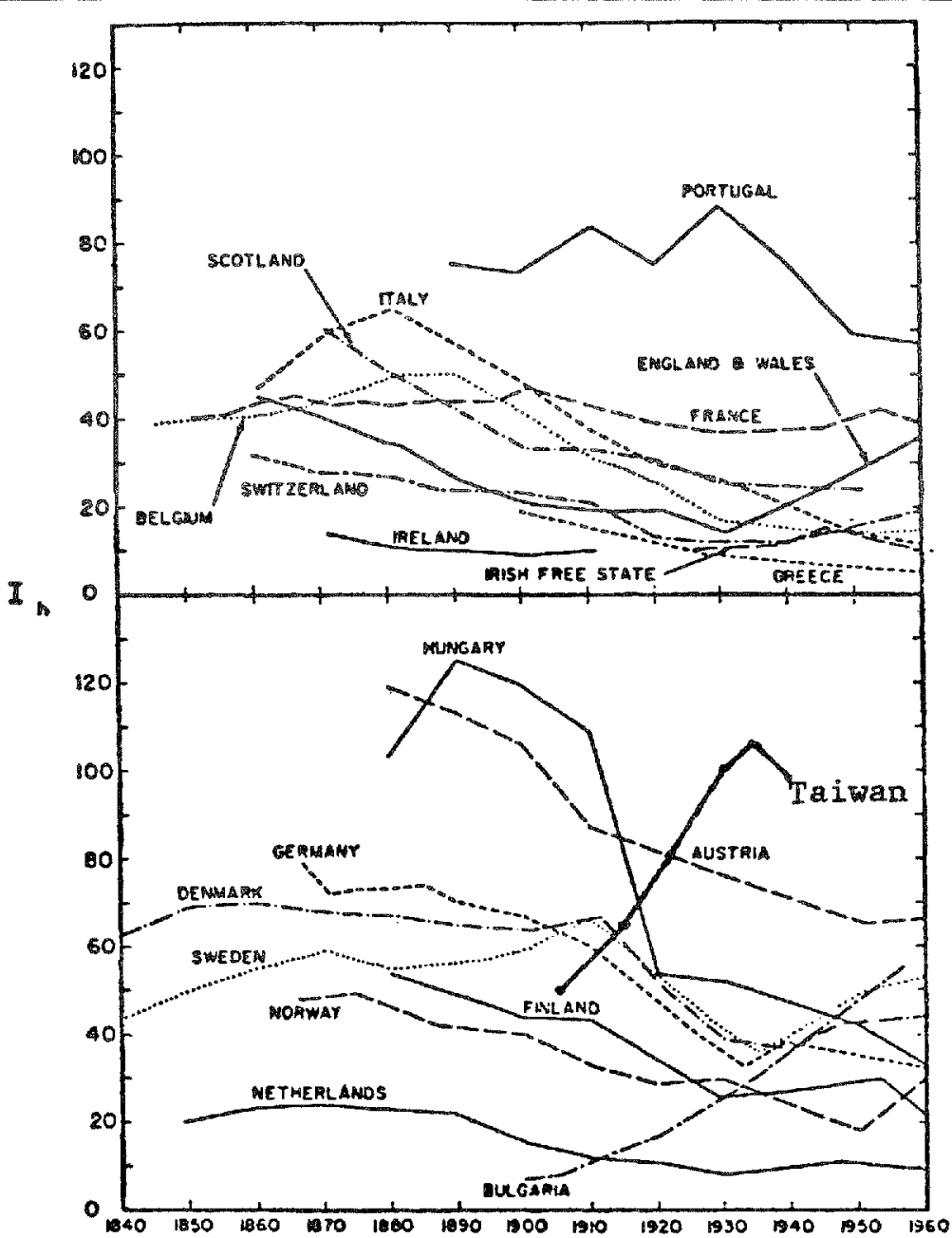

Note: Reliable data on illegitimacy in Taiwan are not available prior to 1906 or after 1942. This figure is adapted from the similar figure in Shorter, Knodel and van de Walle, 1971:391, and the European data are reprinted with the permission of the authors.

and effort to reconstruct the original household registers from various localities. Of course, researchers who wish to generalize from the results of local area studies should be cautioned by the considerable variation in the rates and ratios of illegitimacy between regions.

\section{Taiwanese Bastardy in International} Perspective

Figure 4 shows the levels of illegitimacy measured by Coale's Index of Non-Marital Fertility, the $I_{h}$, in a variety of European countries between 1840 and 1960 and in 
Taiwan between 1906 and 1940. Even at the first date for which reliable data are available, Taiwan's $t_{h}$ was only exceeded by those for Sweden, Denmark, Germany, Austria, Hungary and Portugal. By 1940 , Taiwan's I $h$ was higher than that of any of these European nations, a trend partially explained by the general decline in illegitimacy in Europe which accompanied the demographic transition. But the relatively sharp rise in illegitimacy measured by the $I_{h}$ in Taiwan also contributed to this contrast.

It would be advisable to have further data on Ch'ing Dynasty (before 1895) or modern (after 1945) trends in illegitimacy before making broad generalizations about the significance of the Japanese colonial data. Yet on the basis of the available historical evidence, there is little reason to believe that illegitimacy was significantly lower during the late Ch'ing Dynasty period than it was during the early years of the Japanese household registration system. Further, the rise in illegitimacy during the colonial period does not appear to have been directly associated with any "modernization" of social conditions during that time. As Barclay and numerous other observers have stressed, the economic development of Taiwan-or more accurately, its agricultural development-was not accompanied by much significant "social development" in marriage or family patterns (see Barclay, 1954a; Kerr, 1974; and Chen, 1955a, 1955b).

The lack of any readily available data on the modern period precluded the analysis of current trends in illegitimacy in this article. However, some scattered data from different regions of Taiwan leads me to speculate that at present about 1.5 percent of all births are illegitimate, compared with about 4 percent during much of the Japanese period. I have recently been informed that the Ministry of the Interior may soon publish information on illegiti- mate births in Taiwan; these data may prove to be a useful complement to the extensive published information on total and marital fertility. ${ }^{15}$

Why would the rate of illegitimate births have declined from 1940 to 1978? While Taiwanese tend to marry at older ages today, the wide availability of contraceptives and relatively cheap abortion makes it much easier for mothers to prevent or terminate unwanted pregnancies. Both practices were illegal and unobtainable for the vast majority of women during the Japanese colonial period. ${ }^{16}$

It is possible that at least a small part of the rapid decline in fertility over the past twenty-odd years is due to a decline in nonmarital fertility, as well as a decline in marital rates. In this sense modernization may actually have led to a decline in illegitimacy, a pattern also known in European countries during the twentieth century.

Of course, here I am assuming that fertility among unmarried women in Taiwan really has declined, and this conclusion is based on much less extensive evidence than is available for colonial Taiwan. The modern patterns of bastardy in Taiwan may well show as much variation as those examined here.

${ }^{15}$ Their publication may also allow the Ministry of the Interior to correct one misleading facet of their annual Taiwan Demographic Factbook. Up to now, the "Total Fertility Rate for Currently Married Women" has used all births on the island as the numerator, rather than restricting it to births to currently married women. The use of the latter category in the computation of this rate is recommended by most authorities.

${ }^{16}$ The data on the widespread availability and use of contraception and abortion in modern Taiwan are available in a number of studies; for a useful summary, see Freedman et al., 1974. For data on the legal status of abortion in the Japanese and post-war periods, see Cernada, 1975. 


\section{BIBLIOGRAPHY}

Barclay, George W.

1954a Colonial Development and Population in Taiwan. Princeton: Princeton University Press.

1954b A Report on Taiwan's Population. Princeton: Office of Population Research, Princeton University.

Barclay, George W., Ansley J. Coale, Michael A. Stoto, and James Trussell

1976 "A Reassessment of the Demography of Traditional Rural China." Population Index 42:606-635.

Barrett, Richard E.

1978a "Differential Fertility in Rural Taiwan, 1905-1940." Unpublished Doctoral Dissertation, Department of Sociology, University of Michigan.

1978b "Divorce, Widowhood and Remarriage in Colonial Taiwan: Some New Evidence on the Status of Women in a 'Traditional' Chinese Society." Mimeographed.

Behrman, S. J., Leslie Corsa, Jr., and Ronald Freed. man, eds.

1969 Fertility and Family Planning: A World View. Ann Arbor: University of Michigan Press.

Bureau of Accounting and Statistics (Prowincial Government of Taiwan)

1946 Taiwan Province: Statistical Summary of the Past 51 Years. Taipei: Bureau of Accounting and Statistics, Provincial Government of Taiwan. (in Chinese)

1953 Results of the Seventh Population Census of Taiwan (1940). Taipei: Bureau of Accounting and Statistics, Provincial Government of Taiwan.

Cernada, George P.

1975 "Basic Beliefs About Human Life Relating to Ethical Judgements Family Planning Workers Make About Induced Abortion: Taiwan, 1973." Unpublished Doctoral Dissertation, Population Planning Department, University of California at Berkeley.

Chen, Ching-chih

1975 "The Japanese Adaptation of the Pao-Chia System in Taiwan, 1895-1945." Journal of Asian Studies 32:391-417.

Chen, Shao-hsing

1955a "Population Growth and Social Change in Taiwan." Bulletin of the Department of Archaeology and Anthropology, National Taiwan University 5:76-103. 1955b "Population Change in Taiwan." Bulletin of the Department of Archaeology and Anthropology, National Taiwan University 6:86-119.

Cohen, Myron L.

1976 House United, House Divided. New York: Columbia University Press.

Coale, Ansley J.

1969 "The Decline in Fertility in Europe from the French Revolution to World War II." In S. J. Behrman, Leslie Corsa, Jr., and Ronald Freedman, eds. Fertility and Family Planning: A World View. Ann Atbor: University of Michigan Press.

Freedman, Maurice

1966 Chinese Lineage and Society: Fukien and Kwangtung. London: Athlone Press.

Freedman, Maurice, ed.

1970 Family and Kinship in Chinese Society. Stanford: Stanford University Press.

Freedman, Ronald, Lolagene C. Coombs, Mingcheng Chang, and Te-hsiung Sun

1974 "Trends in Fertility, Family Size Preferences and Practice of Family Planning: Taiwan, 1965-1973." Studies in Family Planning 5, 9:270-288.

Freedman, Ronald, and John Casterline

1979 "The Effect of Nuptiality on Fertility in Taiwan." Paper Presented at the IUSSP Seminar on Nuptiality and Fertility, Bruges, Belgium, Jan. 8-11, 1979.

Gallin, Bernard

1966 Hsin Hsing, Taiwan: A Chinese Village in Change. Berkeley: University of California Press.

Government General of Taiwan

1937 Census of 1935: Statistical Tables. Taihoku [Taipei]: Government General of Taiwan. (in Japanese)

1942 Vital Statistics of Taiwan. Taihoku [Taipei]: Government General of Taiwan. (in Japanese)

1943 Statistics on the Ages of Fathers and Mothers, for Live Births and Stillbirths, 1941. Taihoku [Taipei]: Government General of Taiwan. (in Japanese)

Henry, Louis

1960 "Fécondité légitime de paysans chinois de Formose." Population 15:551-554.

Hsu, Francis L. K.

1971 Under the Ancestor's Shadow. Stanford: Stanford University Press.

Kerr, George $\mathbf{H}$.

1974 Formosa: Licensed Revolution and the Home Rule Movement. Honolulu: University of Hawaii Press.

Knodel, John, and Steven Hochstadt

1976 Illegitimacy in Imperial Germany. Ann Ar- 
bor, Michigan: Center for Western European Studies, University of Michigan.

Laslett, Peter

1977 Family Life and Illicit Love in Earlier Generations. Cambridge: Cambridge University Press.

Lee, Ronald D., ed.

1977 Population Patterns in the Past. New York: Academic Press.

Levy, Marion J., Jr.

1968 The Family Revolution in Modern China. New York: Atheneum.

Okamatsu, Santaro

1971 Provisional Report on Investigation of Laws and Customs in the lsland of Formosa. Taipei: Cheng Wen Publishing Co. [Reprint of 1902 English-language edition published in Kobe, Japan at the "Kobe Herald" Office] Saso, Nariko, and Michael Saso

1975 "A Study of Hsinchu Koseki Registers." National Taiwan University Journal of Sociology 11:61-75.

Shorter, Edward, John Knodel, and Etienne van de Walle

1971 "The Decline of Non-Marital Fertility in Europe." Population Studies 25:375-393.
Shryock, Henry S., and Jacob S. Siegel

1973 The Methods and Materials of Demography. Washington. D.C.: U.S. Government Printing Office.

Taeuber, Irene

1961 "Population Growth in a Chinese Microcosm: Taiwan." Population Index 27:101126.

Tilly, Charles, ed.

1978 Historical Studies of Changing Fertility. Princeton, New Jersey: Princeton University Press.

Tuan, Chi-hsien

1958 "Reproductive Histories of Chinese Women in Rural Taiwan." Population Studies 12: 40-50.

Wolf, Arthur P.

1975 "The Women of Hai-sham: A Demographic Portrait." In Margery Wolf and Roxane Witke, eds. Women in Chinese Society, pp. 89-110. Stanford: Stanford University Press.

Wolf, Arthur P. and Chieh-shan Huang

1980 Marriage and Adoption in China, 18451945. Stanford: Stanford University Press.

Yang, Martin

1968 A Chinese Village. New York: Columbia University Press. 